\title{
Carnitine deficiency is associated with decreased exercise activity in hemodialysis patients
}

Junko Yano', Yusuke Kaida', Yosuke Nakayama', Sakuya Ito', Yuka Kurokawa', Nao Nakamura', Takuma Hazama', Takashi Maeda², Ryuki Hashida², Kyoko Tashiro ${ }^{3}$, Takahiro Inokuchi ${ }^{3}$, Hiroo Matsuse ${ }^{2}$ and Kei Fukami ${ }^{1 *}$

\begin{abstract}
Background and aim: Carnitine deficiency is common and associated with muscle atrophy in hemodialysis (HD) patients. We investigated whether carnitine levels could be an independent predictor for exercise capacity in these patients.

Method: A total of 37 patients (mean age, 55.9 \pm 13.4 years) who underwent HD three times a week were enrolled in this study. Carnitine fraction levels were measured by the enzyme cycling method. Univariate and multiple stepwise regression analyses were performed to determine the correlation between free carnitine levels and the value of exercise capacity examined by the time-up-and-go test (TUG), knee extension strength, functional reach test (FRT), and 10-m walk test, and thigh and calf circumferences as markers of muscle mass.

Results: Serum free carnitine levels were significantly decreased in HD patients. Free carnitine levels were associated with TUG (inversely; $\left.r^{2}=0.120, P=0.035\right)$, knee extension strength $\left(r^{2}=0.129, P=0.029\right)$, FRT $\left(r^{2}=0.246, P=0.002\right)$, and the 10-m walk test (inversely; $r^{2}=0.149, P=0.018$ ). Multiple stepwise regression analysis revealed that free carnitine was an independent predictor for FRT ( $\beta=0.369, P<0.001$ ). There was no correlation between free carnitine levels and thigh and calf circumferences.

Conclusion: Low serum free carnitine levels were associated with decreased exercise capacity in HD patients, suggesting that carnitine deficiency may be a promising therapeutic target for HD-associated muscle weakness in HD patients. This study was retrospectively registered.
\end{abstract}

Keywords: Carnitine deficiency, Exercise, Hemodialysis

\section{Introduction}

Disturbances in exercise activity and frailty are common features of hemodialysis (HD) patients. Approximately $52.6 \%$ and $21.4 \%$ of HD patients were categorized as pre-frailty and frailty, respectively, in Japan [1]. A large number of studies have indicated that decreased exercise activity is associated with derangements in activities of daily living (ADL) and quality of life (QOL) in patients with end-stage renal disease (ESRD). Further, physical inactivity also has been shown to increase the risk of cardiovascular disease (CVD) and could be associated

\footnotetext{
* Correspondence: fukami@med.kurume-u.ac.jp

${ }^{1}$ Division of Nephrology, Department of Medicine, Kurume University School of Medicine, 67 Asahi-machi, Kurume 830-0011, Japan

Full list of author information is available at the end of the article
}

with all-cause and CVD mortality in chronic kidney disease patients [2]. Although several factors, such as malnutrition, inflammation, and anemia have been proposed to contribute to the progression of physical inactivity [3], the precise underlying mechanism of frailty in ESRD patients is not fully understood. Therefore, identification of a novel therapeutic target that could link decreased exercise capacity to $\mathrm{HD}$-associated complications is needed urgently to prevent progression of CVD and improve ADL and QOL in HD patients.

Carnitine is a natural substance that is supplied through the intake of protein-rich foods and synthesized by several organs, such as the liver, kidney, and brain in humans $[4,5]$. Carnitine has a pivotal role for fatty acid $\beta$-oxidation and energy production by transporting

(c) The Author(s). 2019 Open Access This article is distributed under the terms of the Creative Commons Attribution 4.0 International License (http://creativecommons.org/licenses/by/4.0/), which permits unrestricted use, distribution, and 
long-chain fatty acids from the cytoplasm to mitochondria [5]. We, along with others, have reported that serum carnitine levels were significantly decreased in HD patients because $60-80 \%$ of serum carnitine is eliminated from the blood via HD [6, 7]. Since carnitine depletion reportedly has been associated with decreased soleus muscle weight in a rat model of carnitine deficiency [8], carnitine deficiency may be a causative factor for HD-related exercise inactivity in ESRD patients.

However, which anthropometric, metabolic, and clinical variables, including serum free carnitine, are independently correlated with low exercise capacity in these patients remains unclear. Therefore, we examined whether carnitine deficiency was associated with exercise inactivity in HD subjects.

\section{Methods}

\section{Patients}

A complete history, physical examination, and blood chemistry studies were performed in 37 patients (mean age, $55.9 \pm 13.4$ years; mean duration of HD, $153 \pm 67$ months) undergoing chronic HD. Patients were dialyzed for $4-5 \mathrm{~h}$ with high-flux dialyzers three times a week.

\section{Data collection}

The medical history was ascertained by a questionnaire. Vigorous physical activity and smoking were avoided for at least $30 \mathrm{~min}$ before blood pressure measurement.

Blood was drawn from an arteriovenous shunt just before starting the HD sessions to determine hemoglobin, serum albumin, aspartate transaminase, alanine aminotransferase, blood urea nitrogen, creatinine $(\mathrm{Cr})$, uric acid, calcium, phosphate, lipids (total cholesterol, highand low-density lipoprotein cholesterol, and triglycerides), and C-reactive protein. Whole parathyroid hormone was evaluated by an immunoradiometric assay (Allegro I-PTH; Nichols Institute, San Juan Capistrano, CA, USA). Serum carnitine fraction levels were determined as described previously [9]. N-terminal pro-B-type natriuretic peptide (NT-pro BNP) was measured by electro-chemiluminescence immunoassay (SRL, Inc., Tokyo Japan).

\section{Evaluation of physical activity and capacity}

Physical activity and capacity were evaluated by measurement of the time-up-and-go test (TUG), knee extension strength, functional reach test (FRT), 10-m walk test, and thigh and calf circumferences as described previously [10]. All exercise capacities were independently measured once at a day between dialysis sessions by the expert physical therapists at the Division of Rehabilitation, Kurume University Hospital.
Table 1 Clinical characteristics of the patients

\begin{tabular}{ll}
\hline No. of patients & 37 \\
Age (years) & $55.9 \pm 13.4$ \\
Sex (no.) (male/female) & $24 / 13$ \\
HD duration (months) & $153 \pm 67$ \\
BMI (kg/m ${ }^{2}$ & $22.5 \pm 4.1$ \\
Hemoglobin $(\mathrm{g} / \mathrm{dl})$ & $11.7 \pm 1.5$ \\
Serum albumin $(\mathrm{g} / \mathrm{dl})$ & $3.59 \pm 0.24$ \\
AST $(\mathrm{U} / \mathrm{l})$ & $13.6 \pm 7.6$ \\
ALT $(\mathrm{U} / \mathrm{l})$ & $11.9 \pm 7.6$ \\
BUN $(\mathrm{mg} / \mathrm{dl})$ & $60.4 \pm 14.2$ \\
Serum Cr $(\mathrm{mg} / \mathrm{dl})$ & $12.3 \pm 2.3$ \\
Uric acid $(\mathrm{mg} / \mathrm{dl})$ & $7.4 \pm 1.5$ \\
Corrected Ca $(\mathrm{mg} / \mathrm{dl})$ & $8.7 \pm 0.6$ \\
Phosphate $(\mathrm{mg} / \mathrm{dl})$ & $5.1 \pm 1.3$ \\
Total chol $(\mathrm{mg} / \mathrm{dl})$ & $155.0 \pm 29.9$ \\
HDL-chol $(\mathrm{mg} / \mathrm{dl})$ & $46.5 \pm 13.5$ \\
LDL-chol $(\mathrm{mg} / \mathrm{dl})$ & $84.5 \pm 21.2$ \\
Triglycerides $(\mathrm{mg} / \mathrm{dl})$ & $123.6 \pm 94.3$ \\
CRP $(\mathrm{mg} / \mathrm{dl})$ & $0.18 \pm 0.29$ \\
Whole-PTH $(\mathrm{pg} / \mathrm{ml})$ & $131.3 \pm 93.9$ \\
NT-pro BNP $(\mathrm{pg} / \mathrm{ml})$ & $4794 \pm 6125$ \\
Kt/N & $1.74 \pm 0.35$ \\
Free carnitine $(\mu \mathrm{mol} / \mathrm{l})$ & $24.0 \pm 7.3$ \\
Total carnitine $(\mu \mathrm{mol} / \mathrm{l})$ & $40.0 \pm 11.0$ \\
Acyl carnitine $(\mu \mathrm{mol} / \mathrm{l})$ & $16.2 \pm 4.9$ \\
& \\
\hline
\end{tabular}

$\begin{array}{lr}\text { Primary cause of ESRD }(n) & \\ \text { Diabetic nephropathy } & 10(27 \%) \\ \text { Chronic glomerulonephritis } & 10(27 \%) \\ \text { Lupus nephritis } & 3(9 \%) \\ \text { Focal segmental glomerulosclerosis } & 2(5 \%) \\ \text { Hypertensive nephrosclerosis } & 2(5 \%) \\ \text { Others } & 10(27 \%)\end{array}$

Exercise examination

$\begin{array}{ll}\text { TUG }(\mathrm{s}) & 7.2 \pm 1.8 \\ \text { Knee extension strength }(\mathrm{N} / \mathrm{m}) & 27.2 \pm 9.7 \\ \text { Functional reach test }(\mathrm{cm}) & 35.8 \pm 6.7 \\ 10 \mathrm{~m} \text { walk test }(\mathrm{m} / \mathrm{sec}) & 8.2 \pm 1.5 \\ \text { Thigh circumference } 10 \mathrm{~cm}(\mathrm{~cm}) & 39.8 \pm 3.7 \\ \text { Calf circumference }(\mathrm{cm}) & 33.3 \pm 3.7\end{array}$

Abbreviations: $H D$ hemodialysis, $B M I$ body mass index, AST aspartate transaminase, $A L T$ alanine amino transferase, $B U N$ blood urea nitrogen, $\mathrm{Cr}$ creatinine, $\mathrm{Ca}$ calcium, Total chol total cholesterol, HDL-chol high-density lipoprotein cholesterol, LDL-chol low-density lipoprotein cholesterol, TG triglyceride, CRP C-reactive protein, Whole PTH whole parathyroid hormone, $N T$-pro BNP N-terminal pro B-type natriuretic peptide,

ESRD end-stage renal disease, TUG time-up-and-go test 


\section{Statistical analysis}

Data are presented as mean \pm standard deviation. To determine the association between exercise capacity and anthropometric parameters, including serum free carnitine, univariate and multiple stepwise regression analyses were performed. Statistical significance was defined as $P<0.05$. All statistical analyses were performed with the SPSS 19 system (SPSS, Inc., Chicago, IL, USA).

\section{Results}

\section{Demographic data}

Demographic data are shown in Table 1. Free carnitine levels in HD patients were significantly lower than those in healthy controls $(n=21$, mean age $57.0 \pm 7.9$ years old, free carnitine $48.7 \pm 10.1 \mu \mathrm{mol} / \mathrm{l}, P<0.001$ vs HD patients).

\section{Correlation with exercise capacity}

Univariate regression analysis revealed that TUG (inversely, $r^{2}=0.120, P=0.035$, Fig. 1a), knee extension strength $\left(r^{2}=0.129, P=0.029\right.$, Fig. $\left.1 \mathrm{~b}\right)$, FRT $\left(r^{2}=0.246\right.$, $P=0.002$, Fig. $1 \mathrm{c}$ ), and the $10-\mathrm{m}$ walk test (inversely, $r^{2}=0.149, P=0.018$, Fig. 1d) were significantly correlated with free carnitine values (Tables $2,3,4$, and 5 , respectively). There was no significant correlation between circumference of thigh $(P=0.355)$ and calf $(P=0.395)$ and free carnitine levels. The knee extension strength, but not other exercise activities, was stronger in men than in women by univariate analysis $(\beta=-0.530, \quad P=0.01)$.
Multiple stepwise regression analysis showed that free carnitine $(\beta=0.369, P<0.001)$ and serum $\mathrm{Cr}(\beta=0.385$, $P<0.001)$ were independent correlates of FRT $\left(r^{2}=0.246\right.$, Table 4), whereas free carnitine was not an independent determinant of TUG, knee extension strength, and the 10-m walk test (Tables 2, 3, and 5, respectively). Serum $\mathrm{Cr}$ was an independent determinant of these exercise capacities in HD patients (Tables 2, 3, 4, and 5). Further, NT-pro BNP was an independent correlate of the $10-\mathrm{m}$ walk test in these patients (Table 5).

\section{Discussion}

We demonstrated that serum free carnitine levels were decreased in HD patients, low free carnitine levels were significantly correlated with decreased exercise activity except for thigh and calf circumferences in HD patients, and serum free carnitine was an independent determinant of FRT in HD patients.

Free carnitine levels were decreased in our HD patients. Carnitine is not synthesized in skeletal muscle; therefore, circulating free carnitine is the only source of free carnitine levels in skeletal muscles. Indeed, Savia et al. [11] reported that free carnitine levels in skeletal muscles are significantly decreased in HD patients and that a significant positive correlation of free carnitine values between plasma and skeletal muscle is found in these subjects. Therefore, although we did not measure free carnitine levels in skeletal muscle, decreased
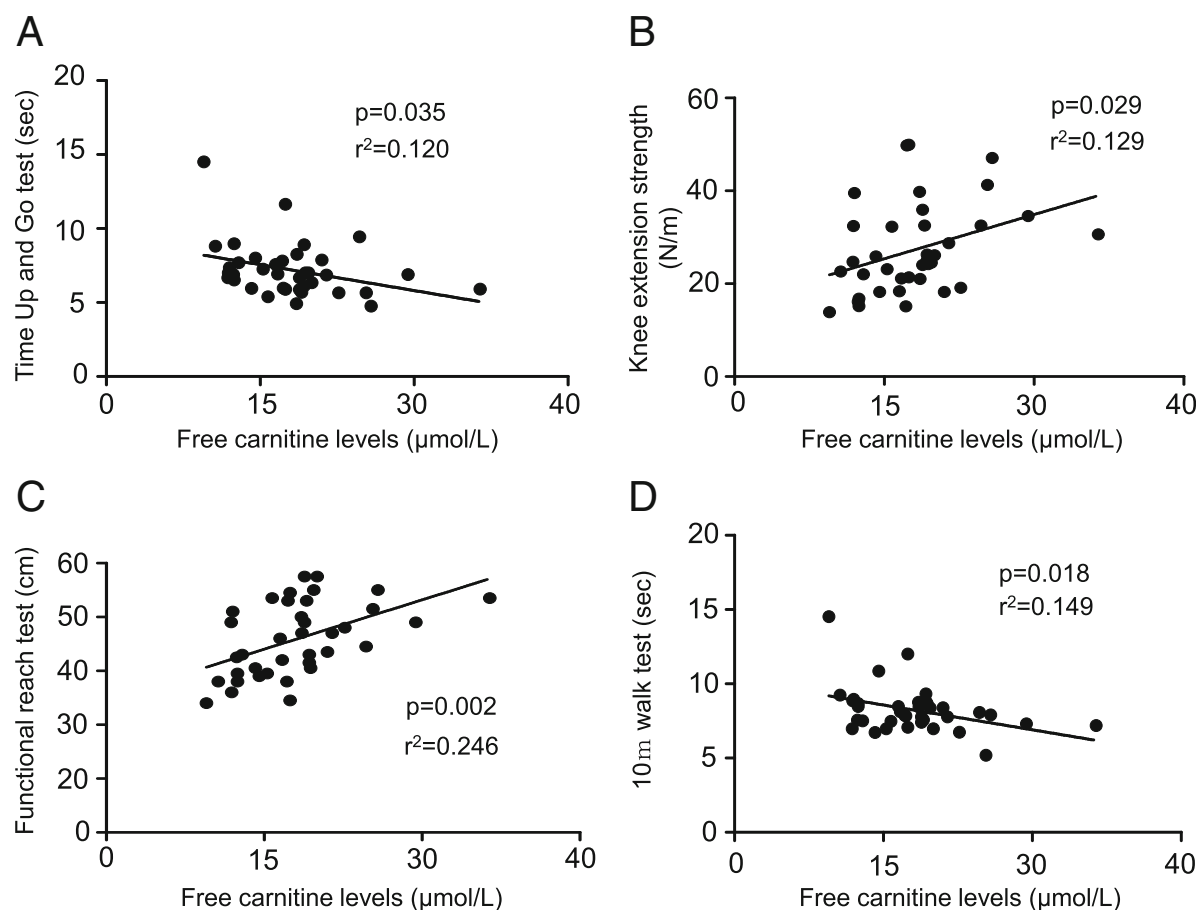

Fig. 1 Univariate regression analysis for the association between serum free carnitine and exercise capacity in HD patients. Correlation between free carnitine levels and the time-up-and-go test (a), knee extension strength $(\mathbf{b})$, functional reach test (c), and the 10-m walk test (d). $n=37$ 
Table 2 Univariate and multiple stepwise regression analysis for the TUG

\begin{tabular}{|c|c|c|c|c|c|c|}
\hline \multirow[t]{2}{*}{ Variables } & \multicolumn{3}{|c|}{ Univariate } & \multicolumn{3}{|c|}{ Multiple stepwise regression } \\
\hline & $\bar{\beta}$ & SE & $P$ value & $\bar{\beta}$ & SE & $P$ value \\
\hline$\overline{\text { Age }}$ & .341 & .022 & 0.039 & & & \\
\hline Sex & -.008 & .627 & 0.963 & & & \\
\hline BMI & .064 & .078 & 0.707 & & & \\
\hline HD duration & -.215 & .005 & 0.201 & & & \\
\hline Hemoglobin & .359 & .186 & 0.029 & & & \\
\hline Serum albumin & -.111 & 1.275 & 0.518 & & & \\
\hline AST & -.010 & .041 & 0.954 & & & \\
\hline ALT & .095 & .042 & 0.577 & & & \\
\hline BUN & -.389 & .020 & 0.017 & & & \\
\hline Serum $\mathrm{Cr}$ & -.607 & .105 & 0.001 & -.501 & .107 & 0.001 \\
\hline Uric acid & -.393 & .182 & 0.016 & & & \\
\hline Corrected Ca & -.036 & .515 & 0.834 & & & \\
\hline Phosphate & -.262 & .226 & 0.117 & & & \\
\hline Total chol & -.475 & .009 & 0.003 & -.293 & .008 & 0.041 \\
\hline HDL-chol & -.267 & .022 & 0.111 & & & \\
\hline LDL-chol & -.415 & .013 & 0.011 & & & \\
\hline Triglycerides & -.072 & .003 & 0.670 & & & \\
\hline CRP & -.139 & 1.058 & 0.413 & & & \\
\hline Whole PTH & -.156 & .003 & 0.355 & & & \\
\hline NT-pro BNP & .429 & .000 & 0.008 & & & \\
\hline Free carnitine & -.347 & .040 & 0.035 & & & \\
\hline $\mathrm{Kt} / \mathrm{N}$ & .101 & .887 & 0.553 & & & \\
\hline
\end{tabular}

$\beta$ standardized regression coefficients, SE standard error. $r^{2}=0.443$

TUG time-up-and-go test, BMI body mass index, AST aspartate transaminase,

ALT alanine amino transferase, BUN blood urea nitrogen, $H D$ hemodialysis,

$\mathrm{Cr}$ creatinine, $\mathrm{Ca}$ calcium, Total chol total cholesterol, HDL-chol high-density lipoprotein cholesterol, LDL-chol low-density lipoprotein cholesterol,

CRP C-reactive protein, Whole PTH whole parathyroid hormone,

$N T$-pro BNP N-terminal pro B-type natriuretic peptide,

circulating free carnitine levels could reflect the deficiency of free carnitine values in the skeletal muscle in our patients.

Although several factors, such as insulin resistance, abnormal protein metabolism, and uremic toxins, have been involved in the loss of skeletal muscle mass in HD patients $[12,13]$, several reports suggest that muscle atrophy is attributed to carnitine deficiency in HD patients $[14,15]$. Given our findings that serum carnitine was an independent correlate of FRT, low carnitine levels may be directly and/or indirectly associated with exercise inactivity in these patients. Serum $\mathrm{Cr}$ has been reported to be strongly correlated with muscle mass and exercise capacity [16, 17]. In our study, serum $\mathrm{Cr}$ was associated positively with serum free carnitine levels $\left(r^{2}=0.107\right.$, $P<0.05)$, so this correlation might explain why carnitine was not an independent determinant of exercise capacity except for FRT. Serum Cr might reflect large skeletal
Table 3 Univariate and multiple stepwise regression analysis for the knee extension strength

\begin{tabular}{|c|c|c|c|c|c|c|}
\hline \multirow[t]{2}{*}{ Variables } & \multicolumn{3}{|c|}{ Univariate } & \multicolumn{3}{|c|}{ Multiple stepwise regression } \\
\hline & $\bar{\beta}$ & SE & $P$ value & $\beta$ & SE & $P$ value \\
\hline Age & -.111 & -.122 & 0.513 & & & \\
\hline Sex & -.530 & 2.80 & 0.001 & -.397 & 2.448 & $<0.0001$ \\
\hline BMl & .071 & .409 & 0.675 & & & \\
\hline HD duration & .119 & .024 & 0.483 & & & \\
\hline Hemoglobin & .082 & 1.048 & 0.630 & & & \\
\hline Serum albumin & .054 & 6.825 & 0.755 & & & \\
\hline AST & -.038 & .214 & 0.821 & & & \\
\hline ALT & .052 & .223 & 0.760 & & & \\
\hline BUN & .259 & .111 & 0.122 & & & \\
\hline Serum $\mathrm{Cr}$ & .599 & .556 & $<0.0001$ & .599 & .556 & $<0.0001$ \\
\hline Uric acid & .223 & 1.017 & 0.185 & & & \\
\hline Corrected Ca & .229 & 2.641 & 0.173 & & & \\
\hline Phosphate & .233 & 1.200 & 0.165 & & & \\
\hline Total chol & -.068 & .055 & 0.688 & & & \\
\hline HDL-chol & .064 & .121 & 0.707 & & & \\
\hline LDL-chol & .021 & .077 & 0.903 & & & \\
\hline Triglycerides & -.241 & .017 & 0.151 & & & \\
\hline CRP & -.105 & 5.593 & 0.534 & & & \\
\hline Whole PTH & .187 & .017 & 0.269 & & & \\
\hline NT-pro BNP & -.013 & .000 & 0.434 & & & \\
\hline Free carnitine & .359 & .209 & 0.029 & & & \\
\hline $\mathrm{Kt} / \mathrm{N}$ & -.359 & 4.383 & 0.029 & & & \\
\hline
\end{tabular}

$\beta$ standardized regression coefficients, SE standard error. $r^{2}=0.506$

$B M I$ body mass index, HD hemodialysis, ALT alanine amino transferase,

AST aspartate transaminase, $\mathrm{Cr}$ creatinine, $\mathrm{Ca}$ calcium, $\mathrm{HDL}$-chol high-density

lipoprotein cholesterol, LDL-chol low-density lipoprotein cholesterol,

CRP C-reactive protein, Whole PTH whole parathyroid hormone,

NT-pro BNP N-terminal pro B-type natriuretic peptide

muscle rather than free carnitine, so free carnitine could not overcome serum $\mathrm{Cr}$ in regard to the correlation with exercise capacity. FRT, a well-recognized method to identify elderly subjects at risk of recurrent falls, not only is a marker of exercise activity, but it also reflects balance performance of the body by using triceps muscle of calf [18]. These findings suggest that carnitine deficiency might aggravate a balance performance, which is a main reason for fall fracture occurring in HD patients. L-carnitine supplementation could prevent muscle wasting in animals with cancer cachexia [19]. In addition, types I and IIa skeletal muscles are more atrophic than type IIb skeletal muscle in HD patients, and L-carnitine supplementation improved the rate of atrophic muscle fiber in types I and IIa muscles, whose energy is supplied by $\beta$-oxidation in HD patients [14]. Further, since oral L-carnitine supplementation has been reported to have some beneficial effects on the physical capacity in HD patients [20], although ours was a cross-sectional 
Table 4 Univariate and multiple stepwise regression analysis for the functional reach test

\begin{tabular}{|c|c|c|c|c|c|c|}
\hline \multirow[t]{2}{*}{ Variables } & \multicolumn{3}{|c|}{ Univariate } & \multicolumn{3}{|c|}{ Multiple stepwise regression } \\
\hline & $\beta$ & SE & $P$ value & $\beta$ & SE & $P$ value \\
\hline Age & -.139 & .085 & 0.411 & & & \\
\hline Sex & -.195 & 2.255 & 0.247 & & & \\
\hline BMI & .032 & .285 & 0.850 & & & \\
\hline HD duration & .051 & .017 & 0.763 & & & \\
\hline Hemoglobin & .723 & -.154 & 0.364 & & & \\
\hline Serum albumin & -.101 & 4.725 & 0.558 & & & \\
\hline AST & -.162 & .149 & 0.925 & & & \\
\hline ALT & .153 & -.172 & 0.310 & & & \\
\hline BUN & .335 & .076 & 0.043 & & & \\
\hline Serum $\mathrm{Cr}$ & .506 & .417 & 0.001 & .385 & .132 & $<0.001$ \\
\hline Uric acid & .286 & .696 & 0.086 & & & \\
\hline Corrected Ca & -.059 & 1.885 & 0.728 & & & \\
\hline Phosphate & .256 & .831 & 0.127 & & & \\
\hline Total chol & .124 & .038 & 0.464 & & & \\
\hline HDL-chol & .124 & .084 & 0.463 & & & \\
\hline LDL-chol & .226 & .052 & 0.179 & & & \\
\hline Triglycerides & -.201 & .012 & 0.232 & & & \\
\hline CRP & .090 & 3.899 & 0.597 & & & \\
\hline Whole PTH & .020 & .012 & 0.234 & & & \\
\hline NT-pro BNP & -.240 & .000 & 0.152 & & & \\
\hline Free carnitine & .496 & .136 & 0.002 & .369 & .132 & $<0.001$ \\
\hline $\mathrm{Kt} / \mathrm{N}$ & -.222 & 3.187 & 0.187 & & & \\
\hline
\end{tabular}

$\beta$ standardized regression coefficients, SE standard error. $r^{2}=0.246$

$B M I$ body mass index, $H D$ hemodialysis, $A L T$ alanine amino transferase, AST aspartate transaminase, $B U N$ blood urea nitrogen, $\mathrm{Cr}$ creatinine, $\mathrm{Ca}$ calcium, Total chol total cholesterol, HDL-chol high-density lipoprotein cholesterol, $L D L$-chol low-density lipoprotein cholesterol, CRP C-reactive protein, Whole PTH whole parathyroid hormone, NT-pro BNP N-terminal pro B-type natriuretic peptide

study and, therefore, did not elucidate the causal relationships between low carnitine and exercise inactivity, decreased carnitine levels may predict the exercise inactivity in HD patients.

Although thigh and calf circumference has been reported to reflect whole muscle mass in type 2 diabetic subjects [21], there was no correlation between thigh and calf circumference and serum free carnitine levels in our subjects. Serum $\mathrm{Cr}$ also did not show any correlation with thigh and calf circumference $(P=0.230, P=0.175$, respectively). It has been suggested that not only skeletal muscle mass but also water and fat contents, which are reduced in HD patients, might affect thigh and calf circumference. Further, muscle quality rather than muscle quantity is thought to be important for exercise activity [22]. Therefore, serum carnitine levels in our study may have reflected muscle quality in HD patients.
Table 5 Univariate and multiple stepwise regression analysis for the 10-m walk test

\begin{tabular}{|c|c|c|c|c|c|c|}
\hline \multirow[t]{2}{*}{ Variables } & \multicolumn{3}{|c|}{ Univariate } & \multicolumn{3}{|c|}{ Multiple stepwise regression } \\
\hline & $\beta$ & SE & $P$ value & $\beta$ & SE & $P$ value \\
\hline$\overline{\text { Age }}$ & .389 & .018 & 0.017 & & & \\
\hline Sex & -.143 & .532 & 0.399 & & & \\
\hline BMI & .075 & .066 & 0.658 & & & \\
\hline HD duration & .083 & .004 & 0.625 & & & \\
\hline Hemoglobin & -253 & .166 & 0.131 & & & \\
\hline Serum albumin & 1.101 & -.098 & 0.570 & & & \\
\hline AST & -.029 & .035 & 0.863 & & & \\
\hline ALT & .184 & .036 & 0.276 & & & \\
\hline BUN & -.340 & .018 & 0.040 & & & \\
\hline Serum $\mathrm{Cr}$ & -.606 & .090 & $<0.001$ & -.347 & .088 & 0.013 \\
\hline Uric acid & -.552 & .142 & $<0.001$ & -.308 & .129 & 0.022 \\
\hline Corrected Ca & -.042 & .441 & 0.806 & & & \\
\hline Phosphate & -.346 & .189 & 0.036 & & & \\
\hline Total chol & -.455 & .008 & 0.005 & & & \\
\hline HDL-chol & -.332 & .019 & 0.044 & & & \\
\hline LDL-chol & -.401 & .012 & 0.014 & & & \\
\hline Triglycerides & -.044 & .003 & 0.797 & & & \\
\hline CRP & -.900 & -.182 & 0.282 & & & \\
\hline Whole PTH & -.139 & .003 & 0.412 & & & \\
\hline NT-pro BNP & -.539 & .000 & 0.001 & .385 & .000 & 0.002 \\
\hline Free carnitine & -.386 & .034 & 0.018 & & & \\
\hline $\mathrm{Kt} / \mathrm{N}$ & .156 & .755 & 0.357 & & & \\
\hline $\begin{array}{l}\beta \text { Standardized re } \\
B M I \text { body mass in } \\
A L T \text { alanine amin } \\
C a \text { calcium, Total } \\
\text { cholesterol, } L D L-C \\
\text { protein, Whole } P T \\
\text { B-type natriuretic }\end{array}$ & $\begin{array}{l}\text { ession } \\
\text { x, HD I } \\
\text { ransfer } \\
\text { ol total } \\
\text { l low-d } \\
\text { whole } \\
\text { ptide }\end{array}$ & $\begin{array}{l}\text { coeffici } \\
\text { emodi } \\
\text { ase, BUI } \\
\text { choles } \\
\text { ensity li }\end{array}$ & $\begin{array}{l}\text { ts, SE stan } \\
\text { ysis, AST as } \\
\text { blood urea } \\
\text { rol, HDL-ch } \\
\text { oprotein cl }\end{array}$ & $\begin{array}{l}\text { dard err } \\
\text { partate } \\
\text { nitroge } \\
\text { ol high- } \\
\text { holester }\end{array}$ & $\begin{array}{l}\text { Crea } \\
\text { ty lip } \\
\text { P C-r }\end{array}$ & $\begin{array}{l}\text { e, } \\
\text { tein } \\
\text { ve } \\
\text { al pro }\end{array}$ \\
\hline
\end{tabular}

NT-pro BNP levels were significantly associated with TUG and the 10-m walk test, but not with knee extension strength and FRT in our HD patients. Although NT-pro BNP has been known to increase in patients with ESRD due to decreased renal excretion, NT-pro BNP might be an important marker of exercise capacity of walking in HD patients.

Several limitations of this study bear mention. First, our study was limited by a small sample size. Second, the study was cross-sectional and could not assess the questions of whether deficient serum carnitine level was a cause or consequence of the decreased exercise activity.

In conclusion, our study suggested that low carnitine levels are associated with decreased exercise activity in HD patients and that carnitine deficiency may be a promising therapeutic target for HD-associated muscle weakness in HD patients. 


\section{Abbreviations}

ADL: Activities of daily living; Cr: Creatinine; CVD: Cardiovascular disease; ESRD: End-stage renal disease; FRT: Functional reach test; HD: Hemodialysis; NT-pro BNP: N-terminal pro-B-type natriuretic peptide; QOL: Quality of life; TUG: Time-up-and-go test

\section{Acknowledgements}

This work was supported in part by a Grant-in-Aid for Welfare, and Scientific Research (C) (no. 22590904) from the Ministry of Education, Culture, Sports, Science and Technology of Japan (KF)

\section{Funding}

Not applicable

\section{Availability of data and materials}

The datasets used and analyzed during the current study are available from the corresponding author on reasonable request.

\section{Authors' contributions}

JY, YK, and YN mainly collected samples, analyzed, and interpreted the patient data. SI, YK, NN, and TH managed hemodialysis patients during the study. TM and $\mathrm{RH}$ collected data regarding the exercise activity. $\mathrm{KT}$ and $\mathrm{TI}$ measured serum carnitine fraction levels in this study. HM deeply interpreted the data of exercise activity. KF was a major contributor in writing the manuscript. All authors read and approved the final manuscript.

\section{Ethics approval and consent to participate}

Informed consent was obtained from all patients, and the study protocol was approved by the institutional ethics committees of Kurume University School of Medicine (Approval Number; 13,282)

\section{Consent for publication}

Not applicable

\section{Competing interests}

KF has received honoraria such as lecture fees from Otsuka Pharmaceutical Co., Ltd. The other authors declare that they have no competing interests.

\section{Publisher's Note}

Springer Nature remains neutral with regard to jurisdictional claims in published maps and institutional affiliations.

\section{Author details}

'Division of Nephrology, Department of Medicine, Kurume University School of Medicine, 67 Asahi-machi, Kurume 830-0011, Japan. ²Division of Rehabilitation, Kurume University Hospital, Kurume, Japan. ${ }^{3}$ Research Institute of Medical Mass Spectrometry, Kurume University School of Medicine, Kurume, Japan.

Received: 14 September 2018 Accepted: 8 January 2019

Published online: 23 January 2019

\section{References}

1. Takeuchi H, Uchida HA, Kakio Y, Okuyama Y, Okuyama M, Umebayashi R, et al. The prevalence of frailty and its associated factors in Japanese hemodialysis patients. Aging Dis. 2018;9(2):192-207. https://doi.org/10. 14336/AD.2017.0429.

2. Warburton DE, Nicol CW, Bredin SS. Health benefits of physical activity: the evidence. CMAJ. 2006:174(6):801-9. https://doi.org/10.1503/cmaj.051351.

3. Johansen KL, Dalrymple LS, Delgado C, Chertow GM, Segal MR, Chiang J, et al. Factors associated with frailty and its trajectory among patients on hemodialysis. Clin J Am Soc Nephrol. 2017;12(7):1100-8. https://doi.org/10. 2215/CJN.12131116

4. Bøhmer T, Hoel P, Purvis K, Hansson V. Carnitine levels in human accessory sex organs. Arch Androl. 1978;1(1):53-9.

5. Evans AM, Fornasini G. Pharmacokinetics of L-carnitine. Clin Pharmacokinet. 2003:42(11):941-67 doi:42112 [pii].

6. Evans A. Dialysis-related carnitine disorder and levocarnitine pharmacology. Am J Kidney Dis. 2003;41(4 Suppl 4):S13-26 doi:S0272638603001136 [pii]

7. Adachi T, Fukami K, Yamagishi S, Kaida Y, Ando R, Sakai K, et al. Decreased serum carnitine is independently correlated with increased tissue accumulation levels of advanced glycation end products in haemodialysis patients. Nephrology (Carlton). 2012;17(8):689-94. https://doi.org/10.1111/j. 1440-1797.2012.01642.x

8. Roberts PA, Bouitbir J, Bonifacio A, Singh F, Kaufmann P, Urwyler A, et al. Contractile function and energy metabolism of skeletal muscle in rats with secondary carnitine deficiency. Am J Physiol Endocrinol Metab. 2015;309(3): E265-74. https://doi.org/10.1152/ajpendo.00001.2015.

9. Takahashi M, Ueda S, Misaki H, Sugiyama N, Matsumoto K, Matsuo N, et al. Carnitine determination by an enzymatic cycling method with carnitine dehydrogenase. Clin Chem. 1994;40(5):817-21.

10. Matsuzawa R, Roshanravan B. Management of physical frailty in patients requiring hemodialysis therapy. Contrib Nephrol. 2018;196:101-9. https://doi. org/10.1159/000485707.

11. Savica V, Bellinghieri G, Di Stefano C, Corvaja E, Consolo F, Corsi M, et al. Plasma and muscle carnitine levels in haemodialysis patients with morphological-ultrastructural examination of muscle samples. Nephron. 1983;35(4):232-6. https://doi.org/10.1159/000183087.

12. Siew ED, Pupim LB, Majchrzak KM, Shintani A, Flakoll PJ, Ikizler TA. Insulin resistance is associated with skeletal muscle protein breakdown in nondiabetic chronic hemodialysis patients. Kidney Int. 2007;71(2):146-52. https://doi.org/10.1038/sj.ki.5001984.

13. Enoki $Y$, Watanabe $H$, Arake $R$, Sugimoto $R$, Imafuku $T$, Tominaga $Y$, et al. Indoxyl sulfate potentiates skeletal muscle atrophy by inducing the oxidative stress-mediated expression of myostatin and atrogin-1. Sci Rep. 2016;6:32084. https://doi.org/10.1038/srep32084

14. Giovenali P, Fenocchio D, Montanari G, Cancellotti C, D'lddio S, Buoncristiani $U$, et al. Selective trophic effect of L-carnitine in type I and lla skeletal muscle fibers. Kidney Int. 1994;46(6):1616-9.

15. Wanic-Kossowska M, Bombicki K, Kozioł L, Czarnecki R. Levels of L-carnitine in serum of patients with chronic renal failure treated by hemodialysis (HD). Pol Arch Med Wewn. 1998:99(4):314-22.

16. Patel SS, Molnar MZ, Tayek JA, Ix JH, Noori N, Benner D, et al. Serum creatinine as a marker of muscle mass in chronic kidney disease: results of a cross-sectional study and review of literature. J Cachexia Sarcopenia Muscle. 2013:4(1):19-29. https://doi.org/10.1007/s13539-012-0079-1.

17. Johansen KL, Chertow GM, Ng AV, Mulligan K, Carey S, Schoenfeld PY, et al. Physical activity levels in patients on hemodialysis and healthy sedentary controls. Kidney Int. 2000;57(6):2564-70. https://doi.org/10.1046/j.1523-1755. 2000.00116.x.

18. Maranesi E, Di Nardo F, Ghetti GG, Mercante O, Rabini RA, Burattini L, et al. Assessment of the activation patterns of the muscles involved in the FR test in diabetic neuropathic patients. Conf Proc IEEE Eng Med Biol Soc. 2015; 2015:6062-5. https://doi.org/10.1109/EMBC.2015.7319774

19. Busquets S, Serpe R, Toledo M, Betancourt A, Marmonti E, Orpí M, et al. Lcarnitine: an adequate supplement for a multi-targeted anti-wasting therapy in cancer. Clin Nutr. 2012:31(6):889-95. https://doi.org/10.1016/j.clnu.2012.03.005.

20. Kudoh Y, Aoyama S, Torii T, Chen Q, Nagahara D, Sakata H, et al. The effects of oral L-carnitine supplementation on physical capacity and lipid metabolism in chronic hemodialysis patients. Nephron Extra. 2014;4(1):33-41. https://doi.org/ $10.1159 / 000360086$

21. Kwon HR, Han KA, Ahn HJ, Lee JH, Park GS, Min KW. The correlations between extremity circumferences with total and regional amounts of skeletal muscle and muscle strength in obese women with type 2 diabetes. Diabetes Metab J. 2011;35(4):374-83. https://doi.org/10.4093/dmj.2011.35.4.374.

22. Seene T, Kaasik P, Riso EM. Review on aging, unloading and reloading: changes in skeletal muscle quantity and quality. Arch Gerontol Geriatr. 2012 54(2):374-80. https://doi.org/10.1016/j.archger.2011.05.002. 